\title{
ABUNDANCE OF IXODES PERSULCATUS TICKS IN KOMI REPUBLIC AS A FUNCTION OF AN AIR TEMPERATURE
}

\author{
A.A. Tronin ${ }^{\mathrm{a}}$, N.K. Tokarevich ${ }^{\mathrm{b}}$, B.R. Gnativ \\ ${ }^{a}$ Scientific Research Center for Ecological Safety, Russian Academy of Sciences, St. Petersburg, Russian Federation \\ ${ }^{b}$ St. Petersburg Pasteur Institute, St. Petersburg, Russian Federation \\ ${ }^{c}$ Center for Hygiene and Epidemiology of Komi Republic, Syktyvkar, Russian Federation
}

\begin{abstract}
The sharp rising incidence of tick-borne encephalitis (TBE) in Komi Republic at the North-east of European Russia was recorded last decades. Tick-bite incidence also was grown. Rapid rise of TBE incidence growth and Ixodidae ticks depends on a number of factors, and the impact of climate change being one of them. Ixodes persulcatus ticks is considered as a main vector of TBE in Komi. Our objective is to estimate the influence of air temperature change on the tickbite incidence and Ixodes persulcatus population in Komi. Komi Republic is located near the Polar circle where the northern frontier of Ixodes persulcatus ticks situated and we expected the growth of tick's population. The number of Komi inhabitants seeking medical care after tick bites in 1992-2014 was considered. Gridded monthly air temperature data with grid size 0.5 degree were recalculated to temperature referred to Komi administrative units. The time series of annual number of tick victims from 1992 till 2014 and model air temperature from 1948 till 2016 for all Komi administrative units were compiled. We analyzed the data on tick-bite incidence in Komi administrative units in relation to changes in local annual average air temperature within the study area. The linear dependence of the tick-bite incidence on air temperature was established when of the tick-bite incidence is represented in logarithm form. The tick population depends not only on temperature but humidity, landcover and hosts. Described areas of Komi belong to humid climate, where precipitations exceed evaporation. Most of the Komi territory is covered by taiga with underwood, grass and bush. Hosts of the first and the major levels are represented by birds and rodents. The dependence of tick-bite incidence and temperature looks like "Malthus's law", but the development of population depends on temperature not on time. The exponential growth in the nearest future will ceased and the population will proceed to stable phase. Ticks population in Komi Republic is moving to the North and the air temperature determines the dynamics of population.
\end{abstract}

Key words: tick-borne encephalitis, tick-bite incidence, Ixodes persulcatus, population, climate change, air temperature, Komi Republic.

\section{ЧИСЛЕННОСТЬ КЛЕЩЕЙ IXODES PERSULCATUS В РЕСПУБЛИКЕ КОМИ КАК ФУНКЦИЯ ТЕМПЕРАТУРЫ ВОЗДУХА}

Тронин А.А. ${ }^{1}$, Токаревич Н.К. ${ }^{2}$, Гнатив Б.P. ${ }^{3}$

${ }^{1}$ Санкт-Петербургский научно-исследовательский центр экологической безопасности РАН, Санкт-Петербург, Россия ${ }^{2}$ ФБУН НИИ эпидемиологии и микробиологии имени Пастера, Санкт-Петербург, Россия

${ }^{3}$ Центр гигиены и эпидемиологии в Республике Коми, г. Сыктывкар, Россия

Резюме. Резкий рост заболеваемостью клещевым энцефалитом зафиксирован в Республике Коми на Северо-Востоке Европейской части России в последние десятилетия. Также выросло число нападений клещей.

\author{
Адрес для переписки: \\ Тронин Андрей Аркадьевич \\ 197110, Санкт-Петербург, ул. Корпусная, 18, \\ Санкт-Петербургский НИЦ экологической безопасности РАН. \\ Тел.: 8 (812) 499-64-54 (служебн.). \\ E-mail: a.a.tronin@ecosafety-spb.ru
}

Библиографическое описание:

Тронин А.А., Токаревич Н.К., Гнатив Б.Р. Численность клещей Iхоdes persulcatus в Республике Коми как функция температуры воздуха // Инфекция и иммунитет. 2019. Т. 9, № 5-6. С. 811-816. doi: 10.15789/22207619-2019-5-6-811-816

(C) Tronin A.A., Tokarevich N.K., Gnativ B.R., 2019

\author{
Contacts: \\ Andrei A. Tronin \\ 197110, Russian Federation, St. Petersburg, Korpusnaya str., 18, \\ Scientific Research Center for Ecological Safety. \\ Phone: +7 (812) 499-64-54 (office). \\ E-mail: a.a.tronin@ecosafety-spb.ru
}

Citation:

Tronin A.A., Tokarevich N.K., Gnativ B.R. Abundance of Ixodes persulcatus ticks in Komi Republic as a function of an air temperature // Russian Journal of Infection and Immunity = Infektsiya i immunitet, 2019, vol. 9, no. 5-6, pp. 811-816. doi: 10.15789/2220-7619-2019-5-6-811-816

DOI: http://dx.doi.org/10.15789/2220-7619-2019-5-6-811-816 
Основным носителем вируса клещевого энцефалита является клещ Ixodes persulcatus. Целью работы является определение влияния изменений температуры воздуха на число нападений клещей на человека и численность популяции Ixodes persulcatus в Коми. Республика Коми находится у Полярного круга, на северной границе ареала Ixodes persulcatus, который, по-видимому, будет расширяться и будет расти численность популяции клещей. В работе рассматривается число обратившихся за медицинской помощью жителей Коми, подвергшихся нападению клещей в 1992-2014 гг. Было проанализировано изменение среднегодовой температуры воздуха и числа пострадавших от нападения клещей. В результате исследований был сделан вывод о расширении ареала клещей на север и определяющей роли температуры воздуха в этом процессе. Зависимость числа пострадавших от температуры похожа на «закон Мальтуса», при этом развитие популяции зависит не от времени, а от температуры воздуха.

Ключевые слова: клещевой энцефалит, нападение клещей, Ixodes persulcatus, популяция, изменение климата, температура воздуха, Республика Коми.

\section{Introduction}

Tick-borne infections are an increasing threat on healthcare in many countries. Tick-borne encephalitis (hereinafter - TBE) was included in the list of notifiable diseases in EU in 2012 [3], and since then it is notifiable in the most of European countries [4]. Clear growth of TBE cases observed in some regions of northern Europe [7, 12, 13]. In 2014, 2057 cases of TBE were notified in the EU. There has been a nearly $400 \%$ increase of reported cases in European endemic areas over the past 30 years [11].

Rapid rise of TBE incidence growth and Ixodidae ticks (main TBE vector) depends on a number of factors $[8,10]$, and the impact of climate change being one of them $[1,6,9]$.

Ixodes persulcatus is considered as the main vector for TBE and Lyme borreliosis in Komi republic at the North-East of European Russia. Ixodes persulcatus is dominating species in Komi Republic [12]. The clear rise of TBE incidence in Komi was recorded last decades, while the annual TBE incidence in Russia has been decreased. We revealed in a strong correlation between the change in the air temperature and TBE incidence and the tick-bite incidence (fig. 1) in neighbor Komi and Arkhangelsk Oblast of Russia [14, 15].

Earlier we also have shown that the increase in average annual air temperature and "effective" temperature (at the period of tick activity) has a significant impact on the northward expansion of ixodid ticks and the rise in TBE incidence in Komi and Arkhangelsk Oblast of Russia [14].

Most of the Komi territory is covered by taiga (about $89 \%$ ), far North-East occupied by tundra (2\%). Other vegetation is represented by intermediate forms, swamps and meadows. Approximately $32,800 \mathrm{~km}^{2}$ of mostly boreal forest (as well as some alpine tundra and meadows) in the Northern Ural Mountains have been recognized in 1995 as a UNESCO World Heritage site, Virgin Komi Forests. It is the first natural UNESCO World Heritage site in Russia and the largest expanse of virgin forests in Europe. Widely spread of Siberian spruce, Scots pine and birch.
Komi climate is cold continental, subarctic. Annual air temperature at the period 1970-2013 was about $-1.3^{\circ} \mathrm{C}$ and tends to growing. Total precipitation are in the range of $600-700 \mathrm{~mm}$ per year, evaporation is about $200-300 \mathrm{~mm}$ per year, so the climate is humid with the prevalence of precipitations above evaporation. Komi consists of 20 administrative units: 19 rural districts and 1 city district (Syktyvkar a capital). Total population of Komi is estimated about 850 thousand in 2017, and Syktyvkar city population -260 thousand.

The main aim of the research was to study the development of I. persulcatus as a population in Komi as a function of air temperature.

\section{Materials and methods}

Epidemiological data. There are two main possibilities to assess the number of ticks in Komi. First is direct collection of ticks from vegetation, second is analysis the number of local inhabitants seeking medical care after tick bites.

Ticks were gathered from vegetation in dull calm days with flannel flag sized $1.0 \times 0.6 \mathrm{~m}$ when the air temperature was $12-18^{\circ} \mathrm{C}$, and humidity $70-90 \%$. Every 5 minutes ticks were removed from the flag using a surgical forceps, placed individually into a glass vial, and delivered to the laboratory during the same day.

The number of Komi inhabitants seeking medical care after tick bites in 1992-2014 was considered. It is very specific parameter recorded by Soviet and Russian medical statistics. Komi population is widely informed about a need to seek medical care in the case of ticks bite. The background information including date and place of the event was provided to Russian Federal Service for Surveillance on Consumer Rights Protection and Human Wellbeing (Rospotrebnadzor) by medical institutions of each Komi district, and the tick-bite incidence rate, i.e. number of tick victims per 100 thousand of population (hereinafter: TBIR) was calculated as follows:

$$
T B I R=N_{t v} \times 100000 / p,
$$


here $N_{t v}$ is number of tick victims within the district under study during the year, and $p$ is the number of the district inhabitants. Syktyvkar city inhabitants are "bitten" by ticks in adjacent Syktyvdinsk district mostly, and for the ease of data processing we considered those two units together.

We analyzed the number of tick victims in the research. The number of tick victims depends not only on ticks abundance but on variation in human activities, the level of medical care and public awareness about ticks danger. We have considered all these reasons in previous research [15] and now can approve the number of ticks in nature is equivalent to the number of tick victims. Thus, the annual number of tick victims referred to Komi administrative units from 1992 till 2014 were involved in processing.

Meteorological data. Meteorological data (air temperature from 1948 to2016) were obtained from National Centers for Environmental Information, USA [5]. Data set "CPC Monthly Global Surface Air Temperature Data Set" is gridded averaged monthly air temperature (at $2 \mathrm{~m}$ altitude). Grid size was 0.5 degree for whole globe and time range covers from 1948 to present time. Gridded monthly air temperature data were recalculated using ArcGIS software to temperature referred to Komi administrative units. The average annual air temperature ATj was calculated from the average monthly values.

$$
A T_{j}=\frac{1}{12} \sum_{i=1}^{12}\left(T_{i j}\right)
$$

here $T_{i j}$ is monthly average air temperature on unit (district of Komi) $j$ in month $i$. This way $A T_{j}$ for all Komi districts were obtained.

The average annual air temperature suffers from strong year-to-year fluctuation. Various methods apply to raw temperature data to select climatic change: averaging, trend compilation. A polynomial function of degree two was calculated for average annual air temperature of Komi administrative units using Microsoft Excel interpolation tools (fig. 2).

When polynomial functions were compiled real air temperature were recalculated to model one to avoid fluctuations. These way model air temperatures (mATj) were calculated for all Komi districts. The time series of annual number of tick victims from 1992 till 2014 and model air temperature from 1948 till 2016 for all Komi administrative units were compiled as a result of preliminary data processing.

\section{Results}

Komi administrative units modeled annual air temperatures were compared with number of tick victims for the same administrative units. Primary sample with 19 districts $\times 23$ years $=437$ records was compiled. Number of tick victims equal to zero was excluded from the data sample. It's mean that no sense to analyze relation between temperature and number of tick victims in area where ticks can't survive. For example, far north administrative units of Komi such as Vorkurta and Inta had annual air temperature below -6 and $-4^{\circ} \mathrm{C}$ respectively at the begin-
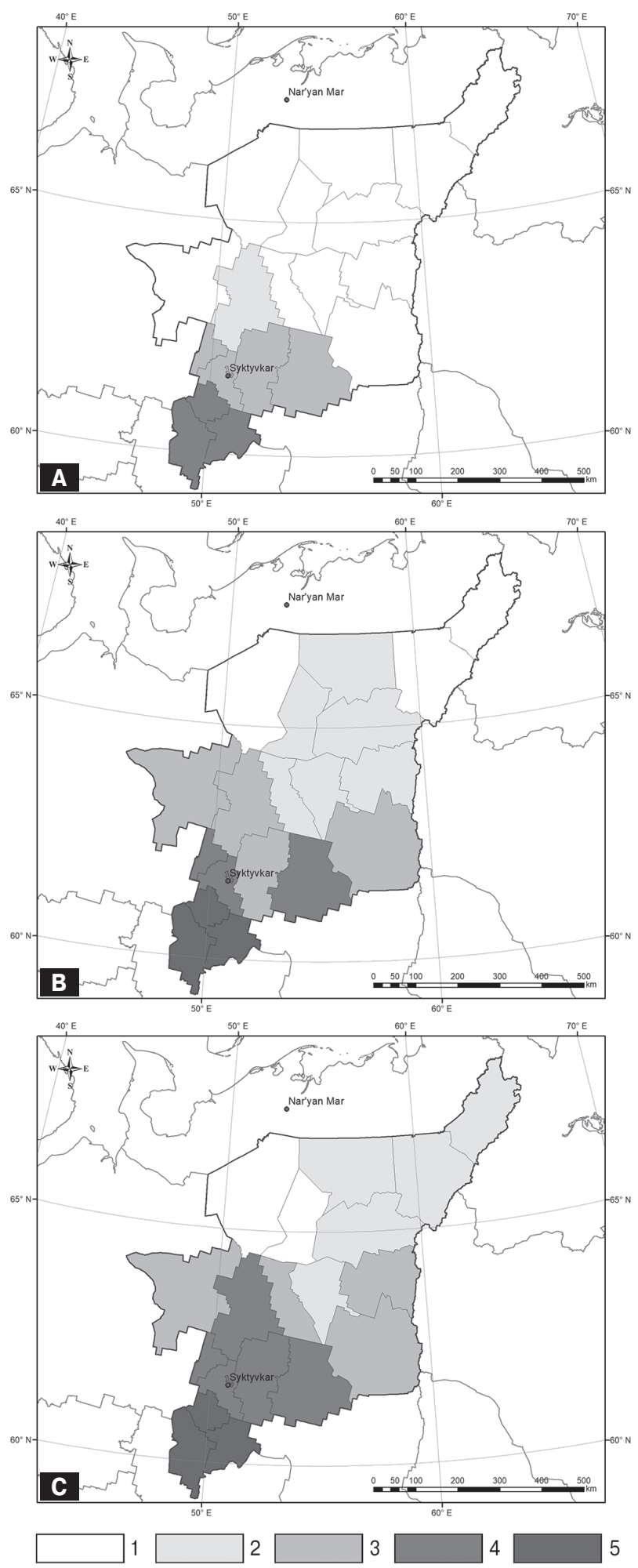

Figure 1. Mean tick-bite incidence rate in Komi districts in 1992-2001 (A), 2002-2011 (B) and 2012-2014 (C)

$1-<0,1 ; 2-0,1-10 ; 3-10-100 ; 4-100-1000 ; 5->1000$. 


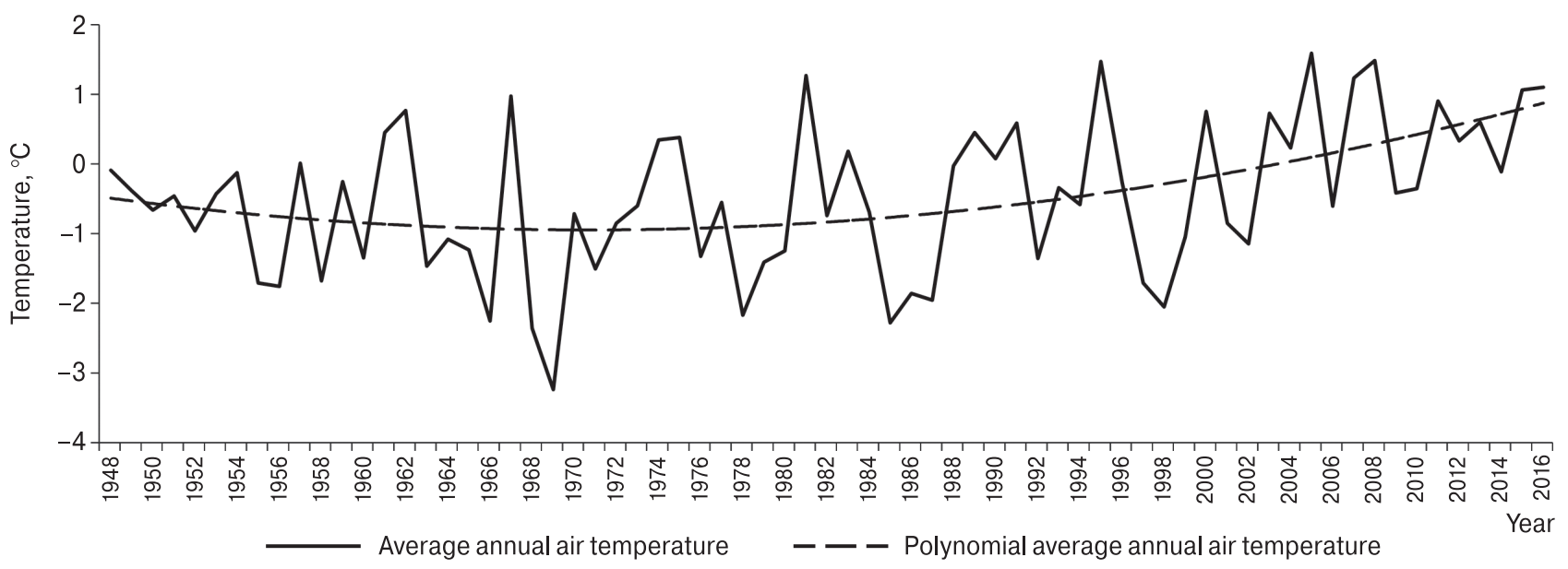

Figure 2. Average annual air temperature and polynomial function of degree two, Uhta administrative units, Komi Republic

ning of $90^{\text {th }}$. Only sporadic cases of tick victims were recorded in these districts. The data sample with 223 conjugate records (modeled annual air temperatures and number of tick victims) was extracted from primary sample. Results are illustrated on figure 3.

Visual analysis indicates the linear dependence of the tick-bite incidence on air temperature when of the tick-bite incidence is represented in logarithm form. Digital solution shows the equation of the regression:

$$
T B I R=15.3 \times e^{1.3934 \times m A T j} .
$$

The Pearson linear correlation coefficient between modeled annual air temperature and a logarithm of number of tick victims was $0.84(\mathrm{p}<0.0001)$.

This is very impressive equation (3) that manifests clear dependence of the number of tick victims and

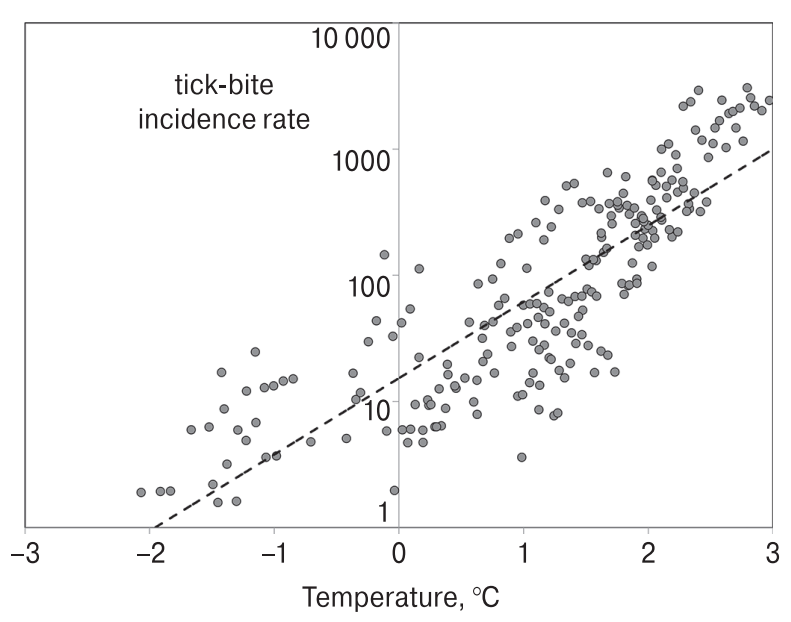

Figure 3. Komi administrative units modeled annual air temperatures and tick-bite incidence rate, 1992-2014. Dashed line shows exponential regression (see equation 3 ) consequently number of ticks on air temperature. And this equation is very similar to so call "Malthus's law" described the exponential unimpeded growth of population in time:

$$
X=X_{0} \times e^{(R \times t)},
$$

where: $X-$ a number of species in a population, $X_{0}-$ initial number of species in a population, $R-$ a coefficient of proportionality (constant in "Malthus's law"), $t$ - time.

\section{Discussion}

Ticks flag collection up to this moment is considered in Russia as a "classical" method to define ticks abundance on local territory. Data were gathered by flag method cannot be extrapolated on vast areas. Unfortunately, tics abundance monitoring doesn't executed at the most of Russian regions [2]. The similar situation is observed in Komi Republic, where direct collection of ticks from vegetation was accomplished in separate years and only in south areas of the republic. It is impossible from practical point of view to build complete database about ticks abundance for Komi Republic based on flag collection.

Thus, we have used another approach to get information about ticks population - the number of tick victims registered by official medical statistics of Komi Republic. This method has some limitation (see "Epidemiological data"), but from the position of practical medicine it provides important information not only about tick abundance but the frequency of tick-human contacts. It is hard to explain of the growth of the number of tick victims in Komi by people awareness as is accompanied by the rise of TBE incidence [15]. Long-term monitoring on the number of tick victims and TBE rate allows us to as- 
sess the real tick population in Komi Republic taking into account high qualification of local medical service.

The weakest thesis in our research is the hypothesis of an adequacy of the number of ticks in nature to the number of tick victims. Obviously not all Komi inhabitants bitten by ticks seek medical care. Various population density and type of inhabitant's activity may to impinge relations between ticks and tick victims. High and persistent tick-bite incidence in some Komi districts says in our hypothesis favor. This value exceeds 1000 in one of the south Komi districts from 2006 till 2014. The crucial importance for our results consists in perennial trend of TBIR not only absolute values. It cannot be excluded the rise of inhabitant's awareness about the danger of tick bites.

Our equation (3) describes the population growth as a function of temperature while "Malthus's law" as a function of time. From the one hand the temperature is a function of time in Komi now (see fig. 3) and we can replace a temperature to time. From the other hand there are no sense to wait the incipience of tick population in areas where the annual temperature below $-4^{\circ} \mathrm{C}$. The tick population depends on temperature, humidity, landcover and hosts. Described areas of Komi belong to humid climate, where precipitations exceed evaporation. Most of the Komi territory is covered by taiga with underwood, grass and bush as was mentioned above that is essential for tick population. Hosts of the first and the major levels are represented by birds with 239 species and 22 species of rodents. Widely spread such large animals as moose, reindeer, gray wolf and even wild boar. This way only the temperature constrains the extension of tick population in north direction. The coefficient of proportionality in equation (3) close to 1 (in our case about 1.4) indicates that the population resides in good condition.

"Malthus's law" is a first step in a population cycle. More comprehensive model describes the limited growth of population as a logistic function or "Verhulst's law". The initial stage of growth is approximately exponential like in "Malthus's law", then, as saturation begins, the growth slows, and at maturity, growth stops.

\section{Conclusion}

Ticks population in Komi Republic spreads to the North and the temperature controls the dynamics of population. The relation of tick victims and temperature looks like "Malthus's law", but the development of population depends on temperature not on time. The exponential growth in the nearest future will ceased and the population will proceed to stable phase. Such stable phase is already observed in south districts of Komi Republic.

\section{References}

1. Второй оценочный доклад Росгидромета об изменениях климата и их последствиях на территории Российской Федерации. Общее резюме. М.: Росгидромет, 2014. 61 c. [Second Roshydromet Assessment Report on Climate Change and Its Consequences in Russian Federation. Moscow: Roshydromet, 2014. 56 p.]

2. Коренберг Э.И., Помелова В.Г., Осин Н.С. Природноочаговые инфекции, передающиеся иксодовыми клещами. М.: Комментарий, 2013. 463 с. [Korenberg E., Pomelova V., Osin N. Infections with natural focality transmitted by Ixodid ticks. Moscow: Kommentarij, 2013. 463 p.]

3. Amato-Gauci A.J., Zeller H. Tick-borne encephalitis joins the diseases under surveillance in the European Union. Eurosurveillance, 2012, vol. 17, no. 42.

4. Amicizia D., Domnich A., Panatto D., Lai P.L., Cristina M.L., Avio U., Gasparini R. Epidemiology of tick-borne encephalitis (TBE) in Europe and its prevention by available vaccines. Hum. Vaccin. Immunother., 2013, vol. 9, no. 5, pp. $1163-1171$. doi: $10.4161 / h v .23802$

5. Fan Y., van den Dool H. A global monthly land surface air temperature analysis for 1948-present. J. Geophys. Res., 2008, vol. 113, pp. $1-18$.

6. Hedlund C., Blomstedt Y., Schumann B. Association of climatic factors with infectious diseases in the Arctic and subarctic region - a systematic review. Glob. Health Action, 2014, no. 7. doi: 10.3402/gha.v7.24161

7. Jaenson T.G., Hjertqvist M., Bergstrom T., Lundkvist A. Why is tick-borne encephalitis increasing? A review of the key factors causing the increasing incidence of human TBE in Sweden. Parasit. Vectors, 2012, no. 5: 184. doi: 10.1186/1756-3305-5-184

8. Knap N., Avšič-Županc T. Factors affecting the ecology of tick-borne encephalitis in Slovenia. Epidemiol. Infect., 2015, vol. 143, no. 10, pp. 2059-2067. doi: 10.1017/S0950268815000485

9. Kř́ž B., KottI., Daniel M., Vráblík T., Beneš Č. Impact of climate changes on the incidence of tick-borne encephalitis in the Czech Republic in 1982-2011. Epidemiol. Mikrobiol. Imunol., 2015, vol. 64, no. 1, pp. 24-32.

10. Ostfeld R.S., Brunner J.L. Climate change and Ixodes tick-borne diseases of humans. Philos. Trans. R. Soc. Lond. B Biol. Sci., 2015, vol. 370, no. 1665, doi: 10.1098/rstb.2014.0051

11. Semenza J., Suk J. Vector-borne diseases and climate change: a European perspective. FEMS Microbiol. Lett., 2018, vol. 365 , no. 2. doi: $10.1093 /$ femsle/fnx244

12. Skarpaas T., Golovljova I., Vene S., Ljøstad U., Sjursen H., Plyusnin A., Lundkvist Å. Tickborne Encephalitis Virus, Norway and Denmark. Emerg. Infect. Dis., 2006, vol. 12, no. 7, pp. 1136-1138. doi: 10.3201/eid1207.051567

13. Suss J. Tick-borne encephalitis 2010: Epidemiology risk areas and virus strains in Europe and Asia - An overview. Ticks Tick Borne Dis., 2011, vol. 2, no. 1, pp. 2-15. doi: 10.1016/j.ttbdis.2010.10.007 
14. Tokarevich N., Tronin A., Blinova O., Buzinov R., Boltenkov V., Yurasova E., Nurse J. The impact of climate change on the expansion of Ixodes persulcatus habitat and the incidence of tick borne encephalitis in the north of European Russia. Glob. Health Action, 2011, no. 4: 8448. doi: 10.3402/gha.v4i0.8448

15. Tokarevich N., Tronin A., Gnativ B., Revich B., Blinova O., Evengard B. Impact of air temperature variation on the ixodid ticks habitat and tick-borne encephalitis incidence in the Russian Arctic: the case of the Komi Republic. Int. J. Circumpolar. Health, 2017, vol. 76, no. 1: 1298882. doi: 10.1080/22423982.2017.1298882

\section{Авторы:}

Тронин А.А., д.г.-м.н., директор Санкт-Петербургского научноисследовательского центра экологической безопасности РАН, Санкт-Петербург, Россия;

Токаревич Н.К., д.м.Н., профессор, зав. лабораторией зооантропонозов ФБУН НИИ НИИ эпидемиологии и микробиологии имени Пастера, Санкт-Петербург, Россия; Гнатив Б.Р., к.М.Н., главный врач Центра гигиены и эпидемиологии в Республике Коми, г. Сыктывкар, Россия.

\section{Authors:}

Tronin A.A.,PhD, MD (Geology and Mineralogy), Director, Scientific Research Center for Ecological Safety, Russian Academy of Sciences, St. Petersburg, Russian Federation;

Tokarevich N.K., PhD, MD (Medicine), Professor, Head of the

Department of Zooanthroponoses, St. Petersburg Pasteur Institute, St. Petersburg, Russian Federation;

Gnativ B.R., PhD (Medicine), Medical Director, Center for Hygiene and Epidemiology of Komi Republic, Syktyvkar, Russian Federation.

Поступила в редакцию 24.12.2018 